\title{
Front Matter: Volume 8074
}

, "Front Matter: Volume 8074," Proc. SPIE 8074, Holography: Advances and Modern Trends II, 807401 (25 May 2011); doi: 10.1117/12.900260

SPIE. Event: SPIE Optics + Optoelectronics, 2011, Prague, Czech Republic 


\title{
PROCEEDINGS OF SPIE
}

\section{Holography: Advances and Modern Trends II}

\author{
Miroslav Hrabovský \\ Miroslav Miler \\ John T. Sheridan \\ Editors
}

18-20 April 2011

Prague, Czech Republic

Sponsored and Published by

SPIE

Cooperating Organisations

ELI Beamlines

HIPER 
The papers included in this volume were part of the technical conference cited on the cover and title page. Papers were selected and subject to review by the editors and conference program committee. Some conference presentations may not be available for publication. The papers published in these proceedings reflect the work and thoughts of the authors and are published herein as submitted. The publisher is not responsible for the validity of the information or for any outcomes resulting from reliance thereon.

Please use the following format to cite material from this book:

Author(s), "Title of Paper," in Holography: Advances and Modern Trends II, edited by Miroslav Hrabovský, Miroslav Miler, John T. Sheridan, Proceedings of SPIE Vol. 8074 (SPIE, Bellingham, WA, 2011) Article CID Number.

ISSN 0277-786X

ISBN 9780819486646

Published by

SPIE

P.O. Box 10, Bellingham, Washington 98227-0010 USA

Telephone +1 3606763290 (Pacific Time) · Fax +1 3606471445

SPIE.org

Copyright (C) 2011, Society of Photo-Optical Instrumentation Engineers

Copying of material in this book for internal or personal use, or for the internal or personal use of specific clients, beyond the fair use provisions granted by the U.S. Copyright Law is authorized by SPIE subject to payment of copying fees. The Transactional Reporting Service base fee for this volume is $\$ 18.00$ per article (or portion thereof), which should be paid directly to the Copyright Clearance Center (CCC), 222 Rosewood Drive, Danvers, MA 01923. Payment may also be made electronically through CCC Online at copyright.com. Other copying for republication, resale, advertising or promotion, or any form of systematic or multiple reproduction of any material in this book is prohibited except with permission in writing from the publisher. The CCC fee code is $0277-786 \mathrm{X} / 11 / \$ 18.00$.

Printed in the United States of America.

Publication of record for individual papers is online in the SPIE Digital Library.

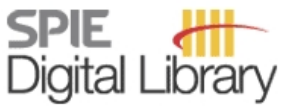

SPIEDigitalLibrary.org

Paper Numbering: Proceedings of SPIE follow an e-First publication model, with papers published first online and then in print and on CD-ROM. Papers are published as they are submitted and meet publication criteria. A unique, consistent, permanent citation identifier (CID) number is assigned to each article at the time of the first publication. Utilization of CIDs allows articles to be fully citable as soon as they are published online, and connects the same identifier to all online, print, and electronic versions of the publication. SPIE uses a six-digit CID article numbering system in which:

- The first four digits correspond to the SPIE volume number.

- The last two digits indicate publication order within the volume using a Base 36 numbering system employing both numerals and letters. These two-number sets start with $00,01,02,03,04$, $05,06,07,08,09,0 A, 0 B \ldots 0 Z$, followed by 10-1Z, 20-2Z, etc.

The CID number appears on each page of the manuscript. The complete citation is used on the first page, and an abbreviated version on subsequent pages. Numbers in the index correspond to the last two digits of the six-digit CID number. 


\section{Contents}

vii Conference Committee

SESSION 1 DIGITAL HOLOGRAPHY AND COMPUTER GENERATED HOLOGRAMS I

807402 Advances in digital holographic microscopy: coherence-controlled microscope (Invited Paper) [8074-01]

R. Chmelik, Brno Univ. of Technology (Czech Republic)

807403 Single particle atmospheric aerosol analysis using digital holographic microscopy [8074-02] M. Mihailescu, National Institute for Research and Development in Microtechnologies (Romania) and Politehnica Univ. from Bucharest (Romania); R. E. Cojocaru, Politehnica Univ. from Bucharest (Romania); C. Kusko, National Institute for Research and Development in Microtechnologies (Romania); F. Toanca, National Institute of Research and Development for Optoelectronics (Romania); A. Dinescu, National Institute for Research and Development in Microtechnologies (Romania); P. Schiopu, Politehnica Univ. from Bucharest (Romania)

807404 Memory efficient noise reduction in in-line Fresnel digital holography [8074-03] N. Pandey, B. Hennelly, National Univ. of Ireland (Ireland)

\section{SESSION 2 DIGITAL HOLOGRAPHY AND COMPUTER GENERATED HOLOGRAMS II}

807405 Digital holography for microscopic imaging and 3D shape measurement (Invited Paper) [8074-04]

J. Buehl, H. Babovsky, M. Grosse, A. Kiessling, R. Kowarschik, Friedrich Schiller Univ. Jena (Germany)

807406 Computer-generated hologram for 3D display from ray information on tilted surface [8074-05]

K. Yamamoto, T. Senoh, R. Oi, Y. Ichihashi, T. Kurita, National Institute of Information and Communications Technology (Japan)

807407 NPDD model: a tool for photopolymer enhancement [8074-46]

M. R. Gleeson, National Univ. of Ireland Maynooth (Ireland); J. Guo, S. Liu, J. T. Sheridan, Univ. College Dublin (Ireland)

807408 Optical reconstruction of three-dimensional object from digital holograms using phase information calculated by continuous wavelet transform [8074-07]

Z. Saraç, Zonguldak Karaelmas Univ. (Turkey); D. Önal Tayyar, F. N. Ecevit, Gebze Institute of Technology (Turkey) 
807409 Synergy of moiré principles and diffraction by periodic structures in optical devices for document security [8074-09]

I. Aubrecht, Police Presidium CR (Czech Republic)

8074 OB Sequential aberrations compensation in an off-axis holographic imaging system [8074-1 1] M. Beuret, Univ. de Strasbourg (France) and INSA Strasbourg (France); D. Vukicevic, P. Twardowski, Univ. de Strasbourg (France); J. Fontaine, Univ. de Strasbourg (France) and INSA Strasbourg (France)

8074 OC Digital holography and phase retrieval: a theoretical investigation [8074-44]

D. P. Kelly, T. Meinecke, N. Sabitov, S. Sinzinger, Ilmenau Univ. of Technology (Germany);

J. T. Sheridan, Univ. College Dublin (Ireland)

\section{SESSION 4 RECORDING MATERIALS AND INFORMATION STORAGE I}

8074 OD Holographic recording diffraction gratings in BB640 photographic emulsions with femtosecond pulses in infrared region (Invited Paper) [8074-12]

A. Fimia, P. Acebal, S. Blaya, L. Carretero, R. F. Madrigal, A. Murciano, J. Neftalí, Univ. Miguel Hernández de Elche (Spain)

$8074 \mathrm{OE} \quad$ Synthesis and properties of 1,3-dioxo-1H-inden-2(3H)-ylidene fragment and (3-(dicyanomethylene)-5,5-dimethylcyclohex-1-enyl)vinyl fragment containing derivatives of azobenzene for holographic recording materials [8074-13]

E. Zarins, V. Kokars, A. Ozols, P. Augustovs, Riga Technical Univ. (Latvia)

8074 OF Photopolymerizable thiol-ene nanocomposite materials for holographic applications [8074-14]

Y. Tomita, E. Hata, S. Yasui, K. Mitsube, Univ. of Electro-Communications (Japan)

8074 OG Theoretical and experimental analysis of chain transfer agents behaviors in photopolymer material [8074-15]

J. Guo, Univ. College Dublin (Ireland); M. R. Gleeson, National Univ. of Ireland Maynooth (Ireland); S. Liu, J. T. Sheridan, Univ. College Dublin (Ireland)

$8074 \mathrm{OH} \quad$ Spectral study of irgacure 784 dye in an epoxy resin photopolymer [8074-16] D. Sabol, Univ. College Dublin (Ireland) and Slovak Institute of Metrology (Slovakia); M. Sabolová, Polymer Institute (Slovakia); M. R. Gleeson, J. T. Sheridan, Univ. College Dublin (Ireland)

\section{SESSION $5 \quad$ RECORDING MATERIALS AND INFORMATION STORAGE II}

8074 OK Experimental research of micro-hologram multiplexing method on thin photosensitive medium in holographic memory [8074-19]

L. D. Sergeevich, O. S. Borisovich, P. A. Yurievich, Bauman Moscow State Technical Univ. (Russian Federation) 
$8074 \mathrm{OL} \quad$ Exploring unconventional capabilities of holographic tweezers (Invited Paper) [8074-21] R. J. Hernandez, Univ. della Calabria (Italy); P. Pagliusi, Univ. della Calabria (Italy) and CNR-IPCF, UOS Cosenza (Italy); C. Provenzano, Univ. della Calabria (Italy); G. Cipparrone, Univ. della Calabria (Italy) and CNR-IPCF, UOS Cosenza (Italy)

8074 OM Holographic fabrication and transmittance analysis of three-dimensional photonic crystals [8074-22]

Y. Ono, M. Notsu, Ritsumeikan Univ. (Japan)

8074 ON New methods of near-field holography [8074-23]

D. E. Silin, Institute of Applied Physics (Russian Federation); I. E. Kozhevatov, Radiophysical Research Institute (Russian Federation)

8074 OP Estimation of quality of 3D holographic images by means of stereogrammetry [8074-24] N. Maryasov, T. Maryasova, National Aviation Univ. (Ukraine); A. Maryasov, Institute of Applied Optics (Ukraine)

$80740 Q \quad$ Measurement of surface resistivity/conductivity of carbon steel in 5-20ppm of TROS C-70 inhibited seawater by optical interferometry techniques [8074-25]

K. Habib, Kuwait Institute for Scientific Research (Kuwait)

\section{POSTER SESSION}

8074 OR Modeling of spatial-frequency spectrum of security holograms and optoelectronic spectrum analyzer for their identification in real time (Invited Paper) [8074-08] A. Zherdev, S. Odinokov, D. Lushnikov, Bauman Moscow State Technical Univ. (Russian Federation)

8074 OT Creation of raster relief structures on silver-halide photographic emulsions with the help of two-dimensional holographic gratings [8074-28]

N. M. Ganzherli, loffe Physico-Technical Institute (Russian Federation); S. N. Gulyaev, St. Petersburg State Polytechnical Univ. (Russian Federation); I. A. Maurer, G. Yu. Sotnikova, D. F. Chernykh, loffe Physico-Technical Institute (Russian Federation)

8074 OU Amorphous As-S-Se semiconductor thin films for holography and lithography [8074-29] V. Kolbjonoks, V. Gerbreders, Daugavpils Univ. (Latvia); J. Teteris, Latvian Univ. (Latvia); A. Bulanovs, Daugavpils Univ. (Latvia)

8074 OV Analysis of the addition of a crosslinking agent in pyrromethene-HEMA based photopolymerizable holographic recording materials [8074-30]

S. Blaya, P. Acebal, L. Carretero, R. F. Madrigal, A. Murciano, A. Fimia, Univ. Miguel Hernández de Elche (Spain)

8074 OW Analysis of the effect modification of the photoinitiator system in pyrromethene-HEMA based photopolymerizable holographic recording materials [8074-31]

S. Blaya, P. Acebal, L. Carretero, R. F. Madrigal, A. Murciano, A. Fimia, Univ. Miguel Hernández de Elche (Spain) 
8074 0X Multiplexed holographic reflection gratings in sol-gel [8074-32]

A. Murciano, S. Blaya, L. Carretero, P. Acebal, R. F. Madrigal, A. Fimia, Univ. Miguel Hernández de Elche (Spain)

8074 OY Technology of integrating diffractive elements into an image-matrix hologram [8074-34] A. Bulanovs, E. Kirilova, V. Gerbreder, Daugavpils Univ. (Latvia)

$80740 Z$ Design and research of parameters of an objective of the ultra-high resolution for producing HOE-DOE by a method a dot-matrix [8074-35]

I. K. Tsiganov, S. B. Odinokov, A. Gerdev, Bauman Moscow State Technical Univ. (Russian Federation); V. V. Pozdnyakov, Joint-Stock Co. (Russian Federation)

807410 Optoelectronic system "HOLOINID" for automatic individualization and identification of security holograms [8074-36]

D. S. Lushnikov, S. B. Odinokov, A. Y. Pavlov, Bauman Moscow State Technical Univ. (Russian Federation)

807411 Axial intensity distribution of converging spherical wave behind an elliptic aperture [8074-37]

M. Miler, T. Martan, Institute of Photonics and Electronics of the ASCR, v.v.i. (Czech Republic)

807413 Simulation analysis of co-axis dual-reference-beam holographic data recording [8074-39] T. Yamada, K. Katakura, A. Nakajima, S. Yoshida, M. Yamamoto, Tokyo Univ. of Science (Japan)

807414 Reduction of zero-order spatial frequencies by using binary intensity and phase modulations in holographic data storage [8074-40]

E. Fernández, A. Marquez, D. Piñol, J. Padilla, I. Pascual, Univ. de Alicante (Spain)

807415 Compact slot-in-type optical correlator for retrieving shape, colour, and texture [8074-41] H. Kuboyama, K. Moriyama, K. Yamaguchi, S. Arai, M. Fukuda, Toyohashi Univ. of Technology (Japan); M. Kato, T. Kawaguchi, PaPaLaB Co., Ltd. (Japan); M. Inove, Toyohashi Univ. of Technology (Japan)

807416 Research of properties of the holographic screen [8074-42]

D. S. Lushnikov, S. B. Odinokov, V. V. Markin, Bauman Moscow State Technical Univ. (Russian Federation)

807417 Coupled-wave theory analysis of holographic structures for slow-light applications [8074-43]

L. Carretero, S. Blaya, A. Murciano, P. Acebal, A. Fimia, R. Madrigal, Univ. Miguel Hernández de Elche (Spain)

Author Index 


\title{
Conference Committee
}

\author{
Symposium Chairs
}

Miroslav Hrabovský, Palacký University Olomouc (Czech Republic)

Wolfgang Sandner, Max-Born-Institut für Nichtlineare Optik und Kurzzeitspektroskopie (Germany) and Laserlab Europe

Bahaa Saleh, CREOL, The College of Optics and Photonics, University of Central Florida (United States)

Jan Rídký, Institute of Physics of the ASCR, v.v.i. (Czech Republic)

Symposium Honorary Chair

Jan Peřina, Sr., Palacký University Olomouc (Czech Republic)

Conference Chairs

Miroslav Hrabovský, Palacký University Olomouc (Czech Republic)

Miroslav Miler, Institute of Photonics and Electronics of the ASCR, v.v.i. (Czech Republic)

John T. Sheridan, University College Dublin (Ireland)

Programme Committee

Radim Chmelik, Brno University of Technology (Czech Republic) Antonio Fimia, Universidad Miguel Hernández de Elche (Spain)

Milos Kopecky, Institute of Physics of the ASCR, v.v.i. (Czech Republic) Libor Kotacka, Optaglio s.r.o. (Czech Republic)

Dagmar Senderáková, Univerzita Komenského v Bratislave (Slovakia) Mitsuo Takeda, The University of Electro-Communications (Japan)

Vladimir Yu. Venediktov, S.I. Vavilov State Optical Institute (Russian Federation)

Przemyslaw W. Wachulak, Military University of Technology (Poland)

Günther K. G. Wernicke, Humboldt-Universität zu Berlin (Germany)

Session Chairs

1 Digital Holography and Computer Generated Holograms I

John T. Sheridan, University College Dublin (Ireland)

2 Digital Holography and Computer Generated Holograms II

Radim Chmelik, Brno University of Technology (Czech Republic) 
3 Security Holography and Holographic Diffractive Optics

Richard M. Kowarschik, Friedrich-Schiller-Universität Jena (Germany)

$4 \quad$ Recording Materials and Information Storage I

Kalaichelvi Saravanamuttu, McMaster University (Canada)

$5 \quad$ Recording Materials and Information Storage II

Miroslav Miler, Institute of Photonics and Electronics of the ASCR, v.v.i. (Czech Republic)

6 Holographic Methods and Other Applications

Antonio Fimia, Universidad Miguel Hernández de Elche (Spain) 